\title{
МІЖ ПРИВАТНИМ ТА ПУБЛІЧНИМ: ПОЛІТИКА ХАННИ АРЕНДТ В ЯКОСТІ БІОГРАФА
}

\section{В.I. Менжулін}

До сотої річниці із дня народження Ханни Арендт

Ханну Арендт (1906-1975) цілком заслужено вважають одним 3 найвпливовіших політичних мислителів ХХ століття. Сьогодні про неї згадують в першу чергу як про поборницю відродження класичного уявлення про політику, як про суворого критика тоталітарних ідеологій та режимів, знавця їхніх джерел тощо. Саме цим темам присвячено найвідоміші праці Ханни Арендт ${ }^{1}$. Широко відомим є також зроблене нею відкриття глибокого зв'язку між зменшенням публічної активності індивідів та зростанням тоталітарних тенденцій в суспільстві, членами котрого вони є. На думку Арендт, забуття індивідами їхньої публічної місіі, занурення у власні приватні проблеми та байдужість до суспільних справ як ніщо сприяють розцвіту тоталітаризму. Це попередження прийнято вважати одним з головних світоглядних «заповітів» Ханни Арендт ${ }^{2}$, а поняття публічності - ледь не перше, що приходить в голову будь-кому, хто намагається сказати про її основні досягнення як філософа.

Разом з тим, в останні роки свого життя ця палка прибічниця публічності випустила збірку праць, яка за самим своїм жанром передбачала визнання факту наявності глибокого взаємовпливу між публічним

\footnotetext{
${ }^{1}$ Такі, скажімо, як [1]; [2].

${ }^{2}$ Наприклад, на цьому наголошується в одному 3 останніх речень статті «Арендт» в «Філософському енциклопедичному словнику», що був виданий Інститутом філософії ім. Г.С. Сковороди НАНУ [6, с. 36].
}

Актуальні проблеми духовності

(Відп. ред.: Я.В. Шрамко)

Кривий Ріг (2007), 75-90 
та приватним шарами людського буття. Йдеться про збірку біографічних есе під загальною назвою «Люди у темні часи» ${ }^{3}$. На нашу думку, зібрані в ній не дуже великі за розмірами біографічні нариси складають неабиякий інтерес. Причому цікаві вони не тільки з точки зору наведеної в них біографічної інформації, але й тим, якої, якщо можна так висловитися, біографічної політики дотримувалася їхня авторка, розповідаючи про життя своїх героїв: яку саме інформацію вона вирішила надати, під яким кутом зору, в якій тональності тощо. Саме політиці Ханни Арендт в якості біографа присвячено дану статтю. Нижче ми спробуємо виділити низку ідей, стратегій, прийомів тощо, що є характерними для біографічного письма Х. Арендт.

Дуже важливі методологічні положення містяться вже у передмові до «Людей у темні часи». Причому стосовно їхнього змісту варто відзначити те ж саме, що було сказане й про жанр збірки в цілому: ці положення дещо не вписуються в спрощені уявлення про Арендт як про затятого проповідника принципу публічності. Авторка збірки не приховує, що серед людей, які стали героями її захоплених біографічних нарисів, є й такі, життя котрих великою активністю на публічній арені не відзначалося. Однак не варто думати, що в даному випадку йдеться про якесь випадкове проникнення «чужорідних» (непублічних, суто приватних, егоїстичних) елементів в тканину біографічних досліджень, орієнтованих виключно на прославлення публічності. Навпаки, Арендт наголошує на тому, що в центрі її уваги знаходитимуться особисті життєві траєкторії героїв, а не те, яким чином ці траєкторії вписуються (якщо вписуються взагалі) у публічно-історичний контекст: «Хто шукає представників епохи, рупорів Zeitgeist, виразників Iсторії 3 великої літери, тут їх не знайде» [3, с. 7$]$.

Взагалі-то, готовність писати книжку про людей, що не були «виразниками Історії з великої літери» (а тим більш-готовність про це настільки відкрито говорити), як за часів публікації «љюей у темні часи», так і пізніше, складала, складає й, наважимося припустити, ще довго складатиме неабиякий професійний ризик для автора. Широка публіка та, відповідно, широке коло професійних біографів традиційно віддають перевагу історіям життя зовсім інших персонажів. Публіка хоче читати як раз про «рупорів» епохи, вона цікавиться в першу чергу життям помітних ${ }^{4}$, видатних, впливових людей. Велика кількість

\footnotetext{
${ }^{3}$ Оригінал-[9]. У подальшому викладі ми будемо посилатися на російський переклад - [3].

${ }^{4}$ Тих, кого помічають, або, якщо російською, «замечают», тобто «замечательных» людей. Звідси й назва однієї з найпопулярніших біографічних серій — «ЖЗЛ»
} 
біографічних творів такого типу та велика повага до них з боку читачів призвели до того, що з'явилася потреба відокремити для них специфічний літературний жанр - «канонічна біографія».

Що дозволило Ханні Арендт піти усупереч цьому «канону»? Як нам здається, тут спрацювало їі фундаментальне (можна сказатиметодологічне) переконання в тому, що «дрібні» історії людей не зникають на тлі універсальної історії людства, час індивідуального буття не розчиняється у бутті історичного часу, а індивід може розглядатися як такий, що великою мірою $є$ автономним від своєї власної епохи. Сказане не означає, що Арендт постала проти «канонічної біографії» як такої. Принципової ворожості по відношенню до такої установки, як бажання дізнатися якомога більше про видатних історичних осіб (i, відповідно, - до такого жанру, як «канонічна біографія»), у Ханни Арендт не було. Вона навряд чи погодилася би з думкою Карла Попера про те, що «наша цивілізація зможе вижити, тільки за тих умов, якщо ми відмовимося від звичного вшанування великих» (Цит. за: [8, c. 178]). Арендт, на відміну від свого маститого сучасника, вважала канонічну біографію надзвичайно перспективним різновидом історичного дослідження. Вона, наприклад, визнавала, що біографії великих нерідко говорять «про відповідний історичний період більше та яскравіше, ніж будь-які - окрім найвидатніших - книжки з історії» [3, с. 44]. Проте авторка «Людей у темні часи» добре усвідомлювала не тільки переваги канонічної біографії ( (Довга, вичерпно документована, з докладними примітками та численними цитатами, вона як правило виходить у вигляді великого двохтомника...»), але й те, що в рамках цього жанру їй не вдасться реалізувати свою основну мету:

Канонічна біографія стала класичним жанром для великих державних діячів, але залишалася мало придатною там, де головний інтерес викликає історія самоӥ людини (курсив мій.B.М.), або для життєписів ... всіх тих, кого геній примушував віддалитися від світу і хто важливі перш за все своєю творчістю, . . . а не роллю, яку вони відігравали [в світі] [3, с. 44].

У зв'язку із подібними міркуваннями може виникнути запитання: якщо йдеться про людину, яка в світі особливої ролі не відігравала, чи не $є$ інтерес до історії її життя суто графоманським? Чи має така біографія якесь значення для нас, тобто для того самого світу, від якого її герой віддалився? Арендт впевнена, що має, хоча й не завжди

(«Жизнь замечательных людей»). 
однаковою мірою. Альтернативні зразки мислення та поведінки стають вкрай потрібні за умов глибокої суспільно-історичної кризи, або, як каже Арендт, у «темні часи». Саме тоді, коли свідомість більшості людей та їхніх кумирів все більш страждає від глобальних світоглядних затьмарень, досвід меншості, маргіналів може стати могутнім терапевтичним засобом ${ }^{5}$. У «темні часи» освітлення приходить не від «рупорів епохи», а «від нечіткого світла, яке мерехтить та часто є слабким, але яке деякі люди у своєму житті та у своїх працях запалюють майже за будь-яких умов...» [3, с.9-10].

Як вже зазначалося, такі персонажі як правило відчувають значний дефіцит уваги не тільки з боку своїх сучасників, але й з боку професійних зберігачів пам'яті про людей минулого, тобто з боку біографів. «Люди у темні часи» - спроба заповнити цю прогалину. Це свого роду зібрання унікальних прийомів, стратегій освітлення, що формувалися та застосовувалися індивідами, які особливо гостро відчували темність часів, в які вони жили. Цілком природно, що перші приклади індивідуального протистояння темряві навколишньої нерозумності авторка «Людей у темні часи» бере з історії власної професії:

Згідно з Хайдеггером, з «неосяжної хтивості» спільного повсякденного світу немає іншого виходу, окрім уходу в ту самоту, яку філософи, починаючи з Парменіда та Платона, протиставляли політичній сфері [3, с. 9].

Однак той факт, що ці філософи згадуються на самому початку книжки (у передмові) зовсім не слідує, що саме цю стратегію «уходу» Ханна Арендт вважає зразковою. Зовсім не однозначно вона оцінює «втечу» Мартина Хайдеггера. 3 одного боку, вона бачить несумнівну «філософську істотність» в закликах Хайдеггера відмовитися від участі у справах «натовпу». В передмові до «Людей у темні часи» вона 3 розумінням говорить про презирство Хайдеггера до «балаканини» та в позитивних тонах цитує широко відому фразу з «Буття та часу»: «світло публічності все затьмарює» $[3, \text { с.9 }]^{6}$. Проте, в іншому місці,

\footnotetext{
${ }^{5}$ До речі, Арендт вважає, що життєписи такого типу можуть бути корисні не тільки в терапевтичному, але й в евристичному плані. Якщо канонічні біографії говорять дуже багато про епоху, в яку жили їхні герої, і таким чином впливають на формування канонічного образу цієї епохи, то біографії альтернативного типу дозволяють побачити епохи, в яких жили їхні герої, у новому (нерідко - дуже несподіваному) ракурсі [3, с. 45].

${ }^{6}$ Ханна Арендт ймовірно має на увазі фразу, яка у перекладі В.В. Бібіхіна звучить так: «Публичность замутняет все и выдает так скрытое за известное и каждому доступное» (Цит. за: [7, с. 127]).
} 
говорячи безпосередньо про часи, що настали зовсім невдовзі після виходу цієї праці, Ханна Арендт знаходить для оцінки «втечі від балаканини» вже зовсім інші вирази:

Як заманливо було б, наприклад, просто ігнорувати нестерпно дурну балаканину нацистів. Але як би не хотілося піддатися такий спокусі та затишно сховатися у внутрішне життя, результатом завжди буде втрата-разом із дійсністю-й самої людяності [3, с. 34].

В той же час Ханна Арендт турбується про те, щоб у розпалі справедливого гніву ми не переплутали подібну нелюдяність з трагічною «внутрішньою еміграцією», що була зумовлена непереборними обставинами. Втеча від світу може бути виправданою за тих умов, говорить Арендт, якщо «ми не закриваємо очі на реальність, але постійно маємо її на увазі як те, від чого ми втікаємо» [3, с. 33]. Не виключено, що певним чином ці міркування стосувалися знов-таки Хайдеггера, однак безпосередньо з тексту це не випливає. Не вдаючись до досить складних особистих мотивів, що неминуче присутні у будь-яких висловлюваннях або умовчаннях Ханни Арендт стосовно Мартина Хайдеггера, відзначимо лише, що серед героїв її спогадів можна зустріти одного німецького філософа, який, якщо слідувати логіці її викладу, точно не може бути запідозрений у нелюдяності.

На відміну від Хайдеггера, цей філософ не те тільки не вважав, що світло публічності щось затьмарює, а, навпаки, «ніколи (курсив мій. B.M.) не поділяв забобону інтелігентних людей, нібито ярке світло публічності робить все дрібним та плоским» [3, с.88], та, взагалі, був першим та єдиним з філософів, «хто виступив проти усамітнення» та заявив, що «істина та комунікація суть одне» [3, с. 101]. Так, був період, коли цьому філософу довелося піти у «внутрішню еміграцію», однак трапилося це під тиском абсолютно непереборних обставин. Йдеться, як можна здогадатися, про одного з найвидатніших спочатку друзів, а пізніше опонентів Мартина Хайдеггера - Карла Ясперса. На сторінках збірки «Люди у темні часи» персоналії автора «Буття та часу» не присвячено жодного есе, іншим героям - по одному, тоді як Карлу Ясперсу - цілі два. Саме життя Ясперса дало Ханні Арендт найбільш за все матеріалу для конструювання свого роду філософсько-біографічної ікони.

Перше з двох есе, що присвячені Ясперсу, має підзаголовок - «Laudatio». У перекладі з латини це означає «схвальне слово». Однак, робить дуже важливе пояснення Арендт, йтиметься про таке схвальне 
слово, яке «має на меті прославити не стільки творчість, скільки саму людину» $[3$, с. 85$]$. Вона збирається розповісти про «гідності, що властиві людині тією мірою, якою вона перевершує всі свої справи та твори» $[3$, с. $85-86]$. Прихильників уявлення, згідно з яким публічному обговоренню можна піддавати тільки «об'єктивні» елементи біографії творчої особистості, тобто її твори, тоді як власно особистість краще віднести до приватної, суто «суб'єктивної» сфери, Арендт називає рабами новітніх забобонів стосовно того, що у житті інтелектуала має бути публічним, а що-непублічним. Арендт впевнена, що згідно із більш давніми та більш істинними уявленнями щодо публічності людина має з'явитися перед публікою в усій своїй суб'єктивності. Більш того, розділення академічної діяльності на «особистісно-суб'єктивні» та «безособистісно-об'єктивні» компоненти, на її думку, має сенс тільки в межах природознавства, тоді як особистість вченого-гуманітарія нерозривно повязана з його науковими дослідженнями.

На думку Арендт, тільки завдяки урахуванню «особистісного» чинника гуманітарні науки можуть розраховувати на збереження за собою права належати до того, що римляни називали humanitas (людяність): «їі (humanitas. - B.M.) набуває лише той, хто піддає своє життя та свою особистість „ризику публічності“...»[3, с. 88]. Зрозуміло, в першу чергу ця вимога стосується політиків. Але не тільки: філософів це торкається також. Саме послідовне визнання філософії такою публічною активністю, яка є дуже спорідненою з політикою, дуже подобалося Ханні Арендт у Карла Ясперса:

Ствердження публічної сфери у Ясперса є унікальним, оскільки воно йде від філософа та $є$ похідним від фундаментального переконання, на якому заснована вся його діяльність в якості філософа: що й філософія, й політика торкаються усіх. Саме це й об'єднує філософію та політику; саме в цьому й полягає причина того, що обидві вони належать публічній сфері, де беруться до уваги людська особистість та її здатність пройти випробування [3, c. 89].

Отже, приклад Ясперса служить для Арендт блискучим підтвердженням того, що об'єктивно-наукові та суб'єктивно-особистісні елементи біографії можуть бути інтегровані в єдиному, цілісному образі мислителя, який свідомо піддає себе ризику публічності ${ }^{7}$. В есе, що присвячені героям, яким, на відміну від Ясперса, не довелося жити в

\footnotetext{
${ }^{7} \mathrm{~B}$ цілому підтримуючі ідею Арендт про те, що біографія саме такого типу $є$ дуже гідною для інтелектуала-гуманітарія, зазначимо, однак, що їй самій у вла-
} 
настільки темні часи, як ера націонал-соціалізму в Німеччині, Арендт більш наполегливо говорить про те, що важливою складовою публічної активності інтелектуала має бути критична налаштованість до світу, особливо - до пануючих в світі догм, стереотипів. Вдалим втіленням такого ідеалу, наочним прикладом «людяності у темні часи» була для неї, наприклад, постать Г.-Е. Лессінга, який «ніколи не заключав перемир'я із світом, в якому жив». Більш за все в біографії Лессінга Ханну Арендт приваблює те, що йому подобалося «давати відсіч забобонам» та «говорити правду придворній черні» [3, с. 14]. Іншого німецького поета (Бертольда Брехта) Арендт критикує за те, що той за певних обставин перестав дивитися на світ власними критичними очима та «слухняно став у строй» $[3$, с. 276].

Однак не слід думати, що Ханна Арендт не уявляла, що повною мірою цей ідеал може бути реалізований лише за ідеальних умов. Переходячи від ідеалів до реальності, вона готова була робити певні винятки. Наприклад, говорила, що в ¥і1̈ власну епоху «геніальність могла розвиватися лише у конфлікті із світом та публічною сферою» [3, с. 12]. Окрім того, згідно з Арендт, бувають й настільки темні часи, коли про конфлікт з публічністю вже не йдеться і зразковою стає скоріше непублічність: «Він завжди стояв цілком один та залишався незалежним від будь-яких угрупувань, - говорить Арендт про позицію Карла Ясперса за часів гітлерівського режиму. - Було самоочевидне, що він залишиться твердим до кінця посеред катастрофи» [3, с.90]. Останній вислів («залишиться твердим до кінця») звучить досить пафосно i, якщо розглядати його поза контекстом, може скластися враження, що Ханна Арендт страждала такою досить поширеною серед біографів (особливо - канонічних) фаховою «хворобою», як надмірне моралізаторство.

Проте є достатні підстави стверджувати, що це не так. Візьмемо, скажімо, ставлення Арендт до Мартина Хайдеггера. Напередодні катастрофи (ще у до-нацистський Німеччині) він пропагував концепцію філософського ескапізму, яка, зрозуміло, є абсолютно неприйнятною з точки зору ідеальних рис, винайдених Арендт у Ясперса або Ле-

сній біографії провести цей принцип з початку до кінця не вдалося. Взяти хоча б її знакові взаємостосунки із Мартином Хайдеггером, які великою мірою й досі залишаються поза зоною дії принципу публічності. Наприклад, авторці нещодавно виданої книжки «Ханна Арендт-Мартин Хайдеггер. Історія взаємовідносин» ([10]) під час її написання довелося обмежитися лише переказом листування між Арендт та Хайдеггером, оскільки публікувати ці принципові матеріали було заборонено (Див. про це: [5, с. 196]). 
сінга. Потім, вже посеред катастрофи, той же Хайдеггер виявився, м'яко кажучи, значно менш твердим і значно більш залежним від «деяких угрупувань», ніж Ясперс. Тим не менш, про зв'язок Хайдеггера 3 націонал-соціалістами Арендт на сторінках «Людей у темні часи» не згадала жодного разу, а про його до-нацистський ескапізм висловилася, як ми пам'ятаємо, навіть в позитивних тонах (див. вище). 3 інших джерел відомо також, що коли Ясперс вимагав від неї рішуче засудити співпрацю Хайдеггера із нацистами, вона категорично відмовилася ${ }^{8}$. Як нам здається, концептуальне виправдання такого специфічного ставлення Арендт до Хайдеггера можна знайти в контексті їі міркувань стосовно долі Езри Паунда - американського поета, біографія якого у певному плані виявилася дуже схожою на хайдеггерівську. Обговорюючи близькість Паунда до нацистів, Арендт звертає увагу ось на що:

Уряд Сполучених Штатів вирішив не придавати його суду за зраду у воєнний час, так як він міг би послатися на неосудність, після чого журі поетів зробило в якомусь сенсі саме те, на що уряд не наважився, - воно судило Паунда, та у підсумку присудило йому премію як кращому поету 1948 року. Поети його нагородили, незважаючи на дурну поведінку або неосудність. Вони судили поета; не їхньою справою було судити громадянина [3, c. 242].

Більш того, Ханна Арендт наголошує на тому, що випадок Паунда $\epsilon$ не одиничним, а, навпаки, типовим:

Поети не часто відрізнялися громадянськими чеснотами; Платон - сам великий поет в обличчі філософа - не перший сердився на поетів. 3 ними завжди було нелегко; вони часто проявляли сумну схильність до непригожої поведінки» [3, с. 241-242].

Посилаючись, що Паунда судили виключно як поета, Ханна Арендт виступає за те, щоб й інших поетів судили в першу чергу як поетів. Присутність в цих i міркуваннях постаті Платона, причому саме в ролі моста між поезією та філософією («поет в обличчі філософа»), як нам здається, дає всі підстави спроектувати сказане про Паунда

\footnotetext{
81956 р. Ясперс, як зізналася Арендт у приватному порядку, ледь не в ультимативній формі вимагав від неї повного припинення відносин з Хайдеггером. Як сказала Арендт своєму конфіденту, «Я була обурена та заявила, що не дозволю ставити мені ультиматуми» (Докладніше про це: [5, с.508]).
} 
на ще одного філософа, який не відрізнився громадськими чеснотами в епоху нацизму, але філософія якого відрізнялася надзвичайною спорідненістю з поезією, тобто на Хайдеггера. Судити Хайдеггера та інших філософів, за логікою Арендт, мають в першу чергу філософи, причому виключно як філософа. Подібна логіка, зрозуміло, несе в собі загрозу упередженості ${ }^{9}$, але принаймні в межах біографічного жанру вона певною мірою виправдана. Один з основних імперативів, які ми знаходимо у підгрунті багатьох біографічних міркувань авторки «Людей у темні часи», можна передати, наприклад, таким чином:

Герой біографічної оповіді вже не зможе відповісти на питання читача, це доведеться зробити автору. Майбутне - це суд над минулим, але імператив безвідповідності робить цей суд наперед визначеним. ... Сказане не означає, однак, що сюжет та персонажі минулого $є$ непідсудними дню сьогоднішньому. Зазначений імператив лише переконує біографа зайняти таку позицію, щоб він не міг претендувати на харизму абсолютної влади над минулим $[4$, с. 49$]$.

3 вищесказаного випливає, що фундаментальною умовою можливості якісної біографії є поважливе, дружнє ставлення біографа до свого героя. Принципова відсутність хоча б базової дружності робить біографа байдуже-відстороненим або жорстко-критичним. Байдужі біографії читати нецікаво, а надто критичні - неприємно. 3 іншого боку, повне злиття біографа із своїм героєм також не може вважатися нормою. Якщо між біографом та героєм зникає дистанція, біографія перетворюється на агіографію. Образно кажучи, бажано, щоб дружній інтерес не переростав у сліпу любов. На подібні роздуми наштовхує, наприклад, есе Ханни Арендт, що присвячено Лесінгу. Останній був великим прихильником активної комунікації, «хотів бути другом багатьох людей, але нічиїм братом (курсив мій. - В.М.)». Він не терпів самоти, але не менш нестерпною для нього була «надмірна близъкість

\footnotetext{
${ }^{9}$ Принаймні, якщо скористатися цією логікою суто формалістино (софістично), мабуть, доведеться визнати, що ще краще, щоб Хайдеггера судили тільки філософи-поети, оскільки, наприклад, філософи-науковці навряд чи здатні осягнути глибину його поетичного філософування. Потім, можливо, з'ясується, що бажано, щоб суддями обиралися виключно німецькомовні філософи-поети. Врешті-решт, може дійти й до визнання, що важливою умовою справедливого суддівства є симпатія до підсудного. Важко повірити, що подібні висновки свідомо передбачалися авторкою «Людей у темні часи». Однак, скажімо, в одному з есе Арендт говорить про те, що глибоке проникнення Г.-К. Честертона в особистість Св. Фоми походило від простої симпатії одного незграбного товстуна до іншого ([3, с. 293-294]).
} 
братерства (курсив мій.-B.М.), що стирає всі розбіжності...»[3, c.42]. Для Лесінга, як й для Арендт, дуже важливою рисою дружби $\epsilon$ те, що вона «не інтимно особистісна, але висуває політичні вимоги та залишається пов'язаною із світом» [3, с. 37]. Відповідно, біограф, який ставиться до свого героя дружньо, але не зливається з ним у беззастережній братський любові, уникає небезпеки бути нудно байдужим або нездорово гіперкритичним, однак залишає за собою право для грунтовної, доброзичливої критики.

Як нам здається, роздуми авторки «Людей у темні часи» стосовно такої категорії як «дружність» цікаві не тільки з точки зору біографіки як окремого напрямку досліджень, але й з огляду на місце біографічного підходу в масштабах всього історико-філософського пізнання. В наші дні дружбу зазвичай прийнято ототожнювати із особистою близькістю, чимось виключно суб'єктивним. Відповідно, введення біографічного (дружнього, особистісного) елементу в історико-філософське дослідження асоціюється з його суб'єктивізацією. В цьому плані дуже доречними, як нам здається, є зауваження Ханни Арендт стосовно власне «суб'єктивності» дружби. Як виявляється, таке уявлення сформувалося порівняно нещодавно, а, скажімо, для давніх греків поняття дружби було значно більш об'єктивним. За їхніми переконаннями, «сутність дружби полягала у розмові. Вони вважали, що тільки постійна співбесіда об'єднує громадян у поліс» [3, с. 35]. Однак дружня бесіда не тільки робила людей політичними. Вона також робила речі людяними. Будь-які предмети набували для греків статус людяності тільки тоді, коли їх можна було обговорити у дружній бесіді із рівними. Римський варіант людяності (humanitas) якогось предмету також передбачав в першу чергу його дружнє обговорення в колі освічених римлян. Однак у модерні часи поняття humanitas зазнало радикальної трансформації: гуманітарні предмети перетворилися на відсторонене знання, тобто на науки, яким треба навчатися, як чомусь такому, що $€$ автономним від дій окремих людей, тим більш-від якихось дружніх бесід. Відповідно, стало можливим розглядати історію філософії як певний відсторонений процес, який можна вивчати, не будучи його активно діючим учасником.

В домінуючих на сьогодні наукоподібних хронологічно-систематичних реконструкціях історико-філософського процесу дуже мало людяності, принаймні в її класичному розумінні. Для тих, хто зайнятий оглядом панорами філософської думки, образно кажучи, «від Фалеса до Хабермаса», власне на дружню бесіду з Фалесом або Хабермасом часу не вистачає. За таких умов активізація біографічного підходу 
може розглядатися як свого роду олюднення історії філософії. Біографічний підхід вимагає від історика філософії уважніше дивитися на кожного конкретного філософа і намагатися зав'язати з ним (незважаючи на часову, мовну, культурну, парадигмальну та будь-яку іншу відстань!) дружню філософську бесіду.

Однак реалізація даного проекту можлива лише за умов визнання принципової плюральності самої філософії. Біографічний підхід перетворюється із суб'єктивно-аматорської розваги на по-справжньому серйозне філософське заняття лише для тих, хто впевнений, що єдино істинної філософії не існує. Ханна Арендт виявляється одним з таких принципових плюралістів. Істина, вважає вона, «як тільки її висловлено, миттєво перетворюється на ще одну гадку серед численних інших». Більш того, на думку Арендт, «єдина абсолютна істина, якщо б вона могла існувати, означала б катастрофу. . вона означала б кінець людяності» [3, с. 39]. Велич одного з своїх героїв (Лесінга) вона бачить «не тільки в розумінні, що всередині людського світу не може бути єдиної істини, але й в його радості від того, що її не існує».

Авторка «Людей у темні часи» також із великим захопленням викладає проект обгрунтування фундаментальної плюральності істини в філософії, що був запропонований Карлом Ясперсом. Арендт звертається до його порівняно маловідомої10 праці 1919-го року «Психологія світоглядів», в якій Ясперс «заперечує абсолютність будь-якої доктрини та замінює іï всезагальною відносністю, в якій кожен конкретний філософський смисл стає засобом для індивідуального філософування» $[3$, с. 100]. Філософування стає невіддільним від індивідуального, екзистенційного досвіду того, хто філософує, а отже - від його біографії. Ознайомлення з філософськими системами мислителів, що давно померли, виявляється свого роду оживленням їхніх унікальних екзистенцій. Вивчення філософії перетворюється на комунікацію із філософами - живими та мертвими. Так формується специфічна екзистенційно-комунікативна модель співвідношення актуального філософування та філософської спадщини, яка суттєво відрізняється від традиційних історико-філософських систем:

Ясперс відчував потребу у великих філософах. Й він щедро відплатив їм за допомогу, заснувавши разом з ними «царство духу», в якому вони знов виступають як особи, що говорять - говорять із царства тіней, - та, відійшовши від часових обмежень,

\footnotetext{
10 Ледь не єдиної великої праці Ясперса, що досі не перекладена не тільки українською або російською, але й англійською мовою.
} 
можуть стати вічними супутниками у питаннях свідомості. ... Перш за все потрібно було відмовитися від освяченого традицією хронологічного порядку, в якому нібито існувала наступність, безперервне наслідування, коли кожен філософ вручає істину наступному. ... Ясперс перетворив часову послідовність в просторову співрозташованість... [3, с. 94].

Плюралізм та персоналізм є домінуючими принципами не тільки історико-філософської, але й філософсько-історичної моделі Карла Ясперса. Його широко відома концепція «осьового часу» передбачає синхронізацію таких трьох фундаментальних явиш, як: а) народження цілої низки великих історичних світових цивілізацій; б) зародження у кожній з цих цивілізацій такого специфічного типу світосприйняття, як філософія; та в) поява великих особистостей, «які вже не сприймають себе ... як лише члени відповідної громади, але вважають себе індивідами та вигадують нові індивідуальні образи життя» [3, c. 104]. Отже, за Ясперсом, початок всесвітньої історії був ознаменований зародженням філософії та, що для нас особливо важливо, появою індивідуалізму. Можна сказати й так: згідно з Ясперсом, головне призначення філософії не в «знятті» індивідуального у всезагальному, а навпаки - у культивуванні індивідуального. Історія філософії з історії сходження від абстрактного до конкретного, від нижчого до вищого, від нерозумності до більшої розумності тощо перетворюється на комунікацію рівноправних філософських індивідуальностей. Єдине, чого позбавляється філософський індивід в системі Ясперса, так це права нав'язувати своє індивідуальне філософування в якості універсальної єдиної філософії для інших.

Очевидно, що ясперсівська рішуча критика гегелівського панлогізму ${ }^{11}$ з позицій персоналізму та плюралізму не може не виявитися ще одним аргументом на користь уваги до біографічного елементу в істоpiї філософії. Річ у тім, що як тільки ми перестаємо розглядати розви-

\footnotetext{
${ }^{11}$ Арендт приєднується до цієї критики, однак, на нашу думку, й у неї, й у Ясперса панлогізм по-справжньому критикується тільки на макро-рівні (в масштабах всього історико-філософського процесу). 3 іншого боку, на мікро-рівні до панлогізму вдається й сама Арендт-демонструючи готовність вписувати все розмаїття духовного життя індивідуума до певної універсальної схеми. Наприклад, вона стверджує: «У творах великого письменника ми майже завжди можемо відшукати притаманну тільки йому стійку метафору, в якій вся його творчість нібито сходиться у фокусі». Арендт знаходить подібну універсальну схему й для всього філософування того ж самого Ясперса: «В творчості Ясперса одна з таких метафорслово „ясність“. ... Саме його існування сформоване пристрастю до ясності...» $([3$, c. 89,91$])$
} 
ток філософії як прояв хитромудрої дії світового духу, виникає загроза почати розглядати історію філософії як царину абсолютної випадковості, хаотичності та, відповідно, безсмисленості. Одна з не багатьох можливостей уникнути такого сумного результату - розглядати історію філософії як історію рівноцінних індивідуальних філософій, тобто як історію неповторних інтелектуальних біографій. Життя філософа $\epsilon$ принаймні не менш важливим, ніж його вчення.

Альтернативний проект, згідно з яким «людське життя не має вирішального значення», а «людські справи підпорядковані позалюдському мірилу», почав реалізовуватися ще давніми (найбільш рішучеПлатоном), однак усі сподівання та симпатії Ханни Арендт пов'язані з іншою традицією: «В усякій християнській та пост-християнській філософії-спершу мовчазливо, а з сімнадцятого століття із все більшою наполегливістю, - передбачається, що життя $\epsilon$ вищою цінністю» $[3$, c. 144]. 3 урахуванням цього ретельне зберігання та примноження біографічних компонентів філософування може розглядатися як посильний внесок історико-філософської науки в реалізацію давньої людської мрії (виконанню якої великою мірою присвячено й весь християнський проект) - мрії про подолання людської смертності. В цьому плані для Арендт дуже важливою була ідея Ясперса про співрозташованість філософів різних епох та народів у єдиному царстві духу. Як говорив ще один з героїв «Людей у темні часи» (німецький письменник Герман Брох), скасування хронологічної послідовності та заміна останньої принципом симультанності (одночасності) означає «скасування часу, який поспішає до смерті» [3, с. 153]. Завдяки цьому з'являється можливість «говорити про незабутнє життя та незабутній момент навіть тоді, коли всі про них забули» [3, с. 231].

Визнання можливості скасування хронологічної ієрархії корегує з низкою інших важливих заходів у напрямку деієрархізації історичного мислення, що здійснено авторкою «Людей у темні часи». Важливим досягненням Арендт є методологічна готовність досліджувати діяльність інтелектуальних трікстірв, тобто персонажів, які внаслідок своєї принципової «неформатності» не вписуються у жодну з відомих ієрархій. Більш того, підхід, який запровадила Арендт, взагалі не вимагає від біографа вписувати свого героя в якійсь жорсткий формат. Як говорилося вище, вся книжка «Люди у темні часи» присвячена постатям, які тим чи іншим чином не вписувалися у наявні рубрики, однак навіть серед них можна виділити справжнього «чемпіона з невідформатованості» - Вальтера Беньяміна: 
Щоб як слід зрозуміти Беньяміна та його твори у звичній для нас системі координат, не обійтися без великої кількості негативних суджень. Він був людиною гігантської вченості, але не належав до вчених; він займався текстами та їхнім витлумаченням, але не був філологом; його приваблювала релігія. . . але він не був теологом. . ; він першим у Німеччині переклав Пруста... але не був перекладачем; він рецензував книжки... але не був літературним критиком; він написав книжку про німецьке бароко. . . але не був істориком ані літератури, ані чого-небудь ще. Я сподіваюсь показати, що він був майстром поетичної думки, але ані поетом, ані філософом при цьому він також не був [3, с. 180].

До Арендт дослідження спадщини такого затятого «шахрая-перебіжчика», скоріше за все, було б кваліфіковане як позаакадемічна розвага, однак згодом (не виключено, що великою мірою завдяки Арендт та її однодумцям) вивчення подібних «пограничних» персоналій стало одним з провідних напрямків у розвитку такої академічної дисципліни, як інтелектуальна історія (історія ідей).

Однак цим лібералізація засад історико-біографічного мислення, запроваджена Ханною Арендт, не вичерпується. На сторінках «Людей у темні часи» поряд 3 легітимацією вивчення «пограничних персоналій» зустрічаємо також й аргументи на користь вивчення «пограничних джерел». Наприклад, в есе «Анжело Джузепе Ронкалі: християнин на престолі Св. Петра з 1958 по 1963» Арендт реабілітує та пропонує долучити до біографічної реконструкції таке маргінальне з академічної точки зору джерело, як анекдот. Шукаючи шляхи до осягнення життєвого шляху Ронкалі, Арендт доходить висновку, що їй навряд чи допоможуть численні визнані ватиканською цензурою (тобто виключно схвальні) джерела. «Від такої агіографії мало користі», говорить вона [3, с. 74]. Тим, хто хоче скласти для себе більш-менш повний образ даного героя, Арендт рекомендує звернутися до повідомлень про нього, які за традиційними історіографічними нормами треба було б відкинути з глибоким презирством. Йдеться про «безкінечні історії та анекдоти, що циркулювали Римом протягом довгих чотирьох днів його агонії» [3, с. 74$]$, а найбільш значні з яких, на думку Арендт, так й залишилися невиданими та передавалися лише з уст в уста. Арендт прекрасно усвідомлює, що багато з цих оповідей не піддаються перевірці, однак продовжує наголошувати на необхідності ïx залучення до реконструкції образу героя. Ї̈̈ основний аргумент на підтримку використання анекдотів в біографічному дослідженні звучить так: «Але навіть якщо б їхня вірогідність не підтвердилася, то й 
в якості вигадки вони надто характерні й для самого Папи, й для його репутації, щоб їх не переказати» [3, с. 75].

Визнання «пограничних» персонажів та джерел в якості таких, що заслуговують на серйозну увагу з боку серйозного біографа, є само в собі дуже важливим фактом. Однак, на нашу думку, модель біографіки, що була запропонована Арендт, корисна не тільки тим, що дозволяє розглядати анекдоти в якості своїх джерел, а «невідформатованих нерупорів епохи» - в якості своїх героїв. Ї̈̈ фундаментальна цінність полягає у визнанні того, що історія діяльності людей (зокрема-історія філософії) не може зводитися до історії продуктів цієї діяльності (роль яких в історії філософії виконують філософські тексти та сформульовані в них ідеї). В одному з останніх есе, що містяться в збірці «Люди у темні часи», про це сказано таким чином:

... ми схильні ототожнювати себе із своїми виробами та вчинками і часто забуваємо, що величезніший привілей кожної людини - істотно перевершувати все, що вона може виробити або досягти. ... Людина є білы великою, ніж що-небудь рукотворне. Справжня велич ... виникає лише тоді, коли за осяжним творінням ми відчуваємо істоту, що залишається більш великою та біль таємничою, так як сам твір вказує на особистість, яка стоїть поза ним і сутність якої не може бути ані вичерпана, ані повністю розкрита нічого з того, що вона здатна зробити [3, с. 295].

Слідуючи цим закликам Ханни Арендт, історія такої форми людської діяльності, як філософія, не має права забувати про особистості, що стоять за продуктами цієї діяльності. Історія філософії не може зводитися до історії філософських творінь - текстів та викладених в них ідей. Вона не може забувати про людей, що були творцями цих ідей. Отже, історія філософії немислима без історій філософів. Автор ще живий. Він помирає тільки на той час, поки на місці людяного читача філософських творінь та дружнього співбесідника їхніх творців незаконно орудує хижий та прожерливий споживач філософської продукції, абсолютно байдужий до того, хто був її виробником.

\section{1 Бібліог рафія}

[1] Арендт Ганна. Становище людини / Марія Зубрицька (пер.).Л.: Літопис, 1999. 
[2] Арендт Ханна. Джерела тоталітаризму / Володимир Верлока (пер. з англ.), Дмитро Горчаков (пер. з англ.). - К.: Дух і літеpa, 2002.

[3] Арендт Х. Люди в темные времена. - М.: Московская школа политических исследований, 2003.

[4] Валевский А.Л. Основания биографики. - К.: «Наукова думка», 1993.

[5] Сафрански P. Хайдеггер: германский мастер и его время / Пер. с нем. Т.А.Баскаковой при участии В.А.Брун-Цехового; Вступ. статья В.В.Бибихина. - 2-е изд. - М.: Молодая гвардия, 2005.

[6] Філософсъкий енциклопедичний словник / НАН України; Інститут філософії ім. Г.С. Сковороди / В.І. Шинкарук (голова редкол.). - К. : Абрис, 2002.

[7] Хайдеггер М. Бытие и время / Пер. с нем. В.В.Бибихина.-Изд. 2-е, испр.-СПб.: Наука, 2002.

[8] Эдмондс Д., Айдиноу Д. Кочерга Витгенштейна. История десятиминутного спора между двумя великими философами. - М.: Новое литературное обозрение, 2004.

[9] Arendt H. Men in Dark Times. - New-York: Harcourt, Brace \& Co., 1968.

[10] Ettinger E. Hannah Arendt / Martin Heidegger: Eine Geschichte.München: Piper, 1996. 